\title{
Digital piracy debunked: a short note on digital threats and intermediary liability
}

\author{
Giancarlo F. Frosio \\ Stanford Law School, Stanford University, Stanford, CA, United States of America
}

Published on 23 Mar 2016 | DOI: 10.14763/2016.1.400

\begin{abstract}
In the last two decades, the industry has deployed endlessly the rhetoric of the "digital threat" in order to demand harsher measures against digital piracy. Recently, the "digital threat" discourse called for enhanced liability of online intermediaries, especially those whose platforms may be used to infringe copyright. This short paper shows that the "digital threat" discourse is based on shaky grounds. Two related arguments might run against this approach. First, market conditions might incentivise piracy. Additionally, there are raising doubts over the argument that piracy is a threat to creativity, especially in the digital environment. Overall, it may be hard to find a factual justification for policy decisions based on the "digital threat" discourse. In fact, digital technology seems not to have negatively affected the creation of new works. In contrast, an observation of the literature and quantitative analysis on point may suggest that digital piracy can be an opportunity for the cultural market. Finally, piracy may function as an innovation policy by forcing market players to innovate in response to a consumer demand that widespread piracy highlights.
\end{abstract}

Keywords: Intermediary liability, Piracy, Copyright

\section{Article information}

Received: 22 Jan 2016 Reviewed: 02 Mar 2016 Published: 23 Mar 2016

Licence: Creative Commons Attribution 3.0 Germany

Competing interests: The author has declared that no competing interests exist that have influenced the text.

URL:

http://policyreview.info/articles/analysis/digital-piracy-debunked-short-note-digital-threats-and-inter mediary-liability

\section{INTRODUCTION}

Stuart Brand argued that "information wants to be free, because it has become so cheap to distribute, copy, and recombine - too cheap to meter. It wants to be expensive because it can be immeasurably valuable to the recipient. That tension will not go away ....” (Brand, 1986, p. 86). The digital dilemma lies in that tension (National Research Board, 2000). The search for 
meaningful policy responses to the digital dilemma has now occupied almost two decades. Most likely, we are still short of a satisfactory solution. Fearful of the "darknet", (e.g., Lasica, 2005), in the last two decades, the industry has deployed the rhetoric of the "digital threat" in order to demand harsher measures against digital piracy and illegal peer-to-peer file sharing (Boyle, 2009, p. 54-82). Recently, the "digital threat" discourse called for enhanced liability of online intermediaries, especially those whose platforms may be used to infringe copyright.

In fact, evidence shows that the "digital threat" discourse is based on shaky grounds. Two related arguments might run against this approach. First, market conditions might incentivise piracy. Additionally, there are raising doubts over the argument that piracy is a threat to creativity, especially in the digital environment. Mark Lemley noted:

\begin{abstract}
Efforts to use IP to lock down the Internet have so far failed to stem the unauthorized distribution of content. But contrary to the predictions of IP theory, the result of that failure has not been a decline in creativity. To the contrary, creativity is flourishing on the Internet as never before despite the absence of effective IP enforcement. That is a problem for IP theory, which may not be the main driver of creativity in a world where creation, reproduction, and distribution are cheap. That is increasingly the world in which we will live (Lemley, 2015, p. 460).
\end{abstract}

Overall, it may be hard to find a factual justification for policy decisions based on the "digital threat" discourse.1 Actually, digital technology seems not to have negatively affected the creation of new works, whose encouragement is the main justification to the legal monopoly created by copyright. In contrast, an observation of the literature and quantitative analysis may suggest that digital piracy can be an opportunity for the cultural market. Finally, piracy may function as an innovation policy by forcing the market players to innovate in response to a consumer demand that widespread piracy highlights.

\title{
SEEKING MORE INTERMEDIARY LIABILITY FOR DIGITAL THREATS
}

Overreaching expansion of copyright over creativity has been generally theorised - and implemented in practice in most cases - by policymakers and the entertainment industry to react to the "threat" posed by digitalisation and internet distribution. A paradigmatic example of the "internet threat" discourse is Justice Newman's statement in Universal $v$ Corley. Responding to the requests of the defendants not to use the Digital Millennium Copyright Act (DMCA) as an instrument of censorship, Justice Newman replied: "[h]ere, dissemination itself carries very substantial risk of imminent harm because the mechanism is so unusual by which dissemination of means of circumventing access controls to copyrighted works threatens to produce virtually unstoppable infringement of copyright" (Universal v Corley, 2001, p. 1968).

In fear of the "digital threat", the demonisation of piracy in the digital environment has been on the rise for almost two decades. A heavy-handed anti-piracy campaign has massively hit media and civil society, targeting users and market players, taking to court kids, infants, grandmas, software developers and software providers, taking down emerging business models regardless of their real market impact (e.g., Frosio, 2011). 
More recently, the digital threat discourse resounded in the intermediary liability domain.2 In Dafra,$_{3}$ Justice Solomon from the Brazilian Superior Court of Justice stressed the importance of imposing liability on intermediaries, saying that "violations of privacy of individuals and companies, summary trials and public lynching of innocents are routinely reported, all practiced in the worldwide web with substantially increased damage because of the widespread nature of this medium of expression" (Google Brazil v Dafra, 2014; Frosio, 2014, 31 January). Justice Solomon added that "if Google created an 'untamable monster,' it should be the only one charged with any disastrous consequences generated by the lack of control of the users of its websites" (Google Brazil v Dafra, 2014). In another landmark case recently before the European Court of Human Rights (ECHR), the "internet threat" discourse resurfaced again to impose proactive monitoring obligation on online news portals. Discussing hate speech, rather than copyright infringement, this time, the ECHR noted that, in the internet, "[d]defamatory and other types of clearly unlawful speech, including hate speech and speech inciting violence, can be disseminated like never before, worldwide, in a matter of seconds, and sometimes remain persistently available online." (Delfi AS v Estonia, 2015, § 110)

\section{TAKEDOWNS AND CHILLING EFFECTS}

In order to exempt online service providers from liability, legislatures worldwide enacted DMCA-like notice-and-takedown procedures. Unfortunately, liability concerns of platforms hosting fan-made creativity create relevant chilling effects, 4 which are proved by abundant empirical evidence of "over-removal" by internet hosting providers (e.g., Keller, 2015, 12 October; Seng, 2014; Dara, 2011; Urban \& Quilter, 2006; Heins \& Beckles, 2004). The DMCA takedown process resembles closely a prior restraint to speech (e.g., Seltzer, 2010; Halbert, 2009, p. 948-952; Patten, 2007).5 Under US law, for example, upon request of the rights-holder, the allegedly infringing materials must be taken down expeditiously by the hosting provider to avoid liability. 6 The removal decision is taken by the private web-hosting service and no due process safeguards are in place, except for the counter-notice that the user uploading the material can issue claiming that no infringement has taken place. Even if the work is restored because of the counter-notice, the virality characterising online circulation of fan-made creativity will most likely be doomed. If the work refers to an event of current interest, the news will be obsolete by the time the material is restored.

In a few instances, the takedown process has been effective in silencing political speech. In the 2008 presidential election, groundless DMCA notices were repeatedly used by TV networks to take down campaign commercial or vids and songvids from YouTube that were becoming too viral (e.g., CDT, 2010, pp. 1-19; McKay, 2010, p.137). Recurrently, the notice-and-takedown process silences artistic speech, as in the case, for example, of an anti-piracy firm working for Columbia Pictures that hit Vimeo with a wave of bogus copyright takedowns just because people used the word 'Pixels' in their video titles ("Anti-Piracy Group Hits Indie", 2015). The DMCA notice-and-takedown process has given the copyright holders a new leverage weapon that makes the spectre of copyright shine even brighter in the nebula of "user-generated confusion" (JETL 10th Anniversary Symposium, 2007). However, recent US case law gave some breathing space to "user generated content" (UGC) creators from bogus takedown notices in cases of blatant misrepresentation of fair use defences by copyright holders and held that "the statute requires copyright holders to consider fair use before sending take-down notification" (Lenz v Universal, 2015, p. 5).

\section{EXPANDING INTERMEDIARY LIABILITY AND REFORMING SAFE HARBOURS}

The recent entertainment industry's strategy has been increasingly seeking enforcement of online intermediaries' secondary liability to tackle copyright infringement (IFIP, 2012; IFIP, 
2010; Standeford, 2010; Frabboni, 2010), including especially liability of entrepreneurial service providers of UGC sites (e.g., Ginsburg, 2010, pp. 163-179; Lichtman, 2008), with the overt goal of turning them into their watchdogs. Additional proposed legislations support this trend by increasing the role and liability of Information Service Providers as a tool to target copyright infringement. One pristine example is the now dormant US PROTECT IP and SOPA Act, which might have potentially bypassed the DMCA "safe harbor" provision by placing the responsibility for detecting and policing infringement onto the site itself, and allowing judges to block access to websites "dedicated to theft of U.S. property".7

Another good example of this strategy comes from the recent EU Commission intellectual property action plans (European Commission, 2015). The European Commission would like to introduce enhanced obligations that websites and other internet intermediaries should have for dealing with unlawful third-party content (Ibid., § 3.3). In particular, the Commission is discussing what regulations should apply to a subset of those intermediaries deemed "internet platforms"; and "whether to require intermediaries to exercise greater responsibility and due diligence in the way they manage their networks and systems - a duty of care." (Ibid.). These enhanced responsibilities would apply when intermediaries deal with illegal content, such as child pornography, terrorist materials, and content that infringes upon intellectual property rights (Ibid.). The European Commission is seriously considering narrowing the E-Commerce Directive horizontal liability limitations for internet intermediaries and recently invited all interested parties to express their views on questions targeting relations between platform providers and holders of rights in digital content.8

In a similar fashion, national legislators proposed or implemented enhanced obligations for online intermediaries. In particular, the German coalition agreement of 2014 states that "internet service providers should take more responsibility" to combat mass infringements of copyright (Zeiter, 2014). The grand coalition plans to "improve enforcement in particular towards platforms whose business model is mainly based on the infringement of copyright" (Ibid.). To that end, the coalition would like to "ensure that such service providers no longer enjoy the general liability privilege as so-called hosting provider and in particular no longer receive advertising revenues" (Ibid.). The recent Spanish copyright reform expanded intermediary liability by introducing a doctrine of secondary liability in the copyright act, providing obligations for ISPs to reveal identities of alleged copyright infringers, and expanding the powers of the Copyright Commission - an administrative body which can order injunctions against internet service providers who infringe on copyright (Peguera, 2015). In Italy, the Regulation on Online Copyright Enforcement empowered the Italian Communication Authority's ('AGCOM') to enforce online copyright infringement by ordering access and hosting providers to block access to websites hosting infringing materials or remove allegedly infringing contents after a short administrative procedure (AGCOM, 2013; Frosio, 2013).

\section{BLOCKING ORDERS, PROACTIVE MONITORING, AND THREE-STRIKES}

Meanwhile, blocking orders have been routinely adopted by courts, especially in the UK (Frosio, 2013, 22 September) and Italy (Frosio, 2013, 6 September), both against websites infringing copyright and trademarks (Cartier v BSkyB, 2014; Poulter \& Smith 2014) ). The European Court of Justice (ECJ) backed up this practice stating that EU law must be interpreted as not precluding a court injunction that does not specify the measures which an access provider must take to block access to a website making available copyrighted material without the rights holders' permission (UPC Telekabel v Constantin Film, 2014).

Recently, national courts implemented proactive monitoring obligations for access and hosting 
providers, such as in the Allostreaming case in France (APC v Google, 2013), in apparent conflict with a well settled jurisprudence of the ECJ (SABAM v Netlog, 2012; Scarlet v SABAM, 2011). In Italy, proactive monitoring has been forced upon intermediaries by some courts (Delta TV v YouTube, 2014), whereas other courts took the opposite stance and confirmed that there is no monitoring obligation for intermediaries under European law (RTI v Yahoo! Italia, 2015). Discussing privacy and defamation this time, courts in France and Germany imposed proactive monitoring obligations to search engines, which were ordered to expunge the internet from pictures infringing the privacy rights of Max Mosley - former president of Formula 1 - caught on camera to have sex with prostitutes wearing Nazi paraphernalia (Van Eecke \& Dierick, 2013; Crossley, 2014).

In South America, proactive monitoring obligations have been discussed extensively and courts have applied both strict liability and negligence standards to intermediaries. As mentioned earlier, the Brazilian Supreme Court imposed on YouTube a proactive monitoring obligation and a strict liability standard in the Dafra case (Google Brazil v Dafra, 2014; Frosio, 2014, 31 January).9 In contrast, a recent landmark case decided by the Argentinian Supreme Court rejected any filtering obligation to prevent infringing links from appearing in search engines' results in the future (Belen v Google, 2014; Palazzi \& Jurado 2015). In China, the Beijing Higher People's Court set up a duty to monitor for hosting providers based on popularity of infringed works with high volume views/downloads. According to the High Court of Beijing, by using current technologies, it was reasonable for Baidu to exercise a duty to monitor and examine the legal status of an uploaded work once it has been viewed or downloaded more than a certain number of times (Zhong Qin Wen v Baidu, 2014).

Also, the strategy behind the so-called three-strike regulations, seeking to block out household internet connections of repeat infringers, is to encourage, or force, online intermediaries to exercise policing power on their own over potential infringers (e.g., Swartout, 2011; Strowel, 2010; Benabou, 2010; Sirinelli, 2010). The recently announced Copyright Alert System (CAS) goes in similar direction by setting up a cooperative, multi-stakeholder approach in which information service providers serve as a watchdog of the rights holders and exercise policing power on their own over potential infringers (Lesser, 2013). The CAS would implement a system of multiple alerts, allowing "your ISP [to] undertake measures that will temporarily affect your Internet experience".10

These policy strategies ranging from three-strike regulations to voluntary private enforcement raise censorship concerns, especially in connection to the emerging idea of internet as a fundamental right. Depriving users-and entire households -of access to the internet would imperil their capacity of engaging in fundamental portions of their public life and may result in a disproportionate reaction to copyright infringement that, in any event, should be subject to strict due process checks and balances.

\section{CONDORCET, HIGH PRICES AND BOGUS FIGURES}

The uneasiness in sharing the view that digital piracy mandates "emergency legislation" comes from the uncertain grounds on which the heavy-handed reaction against digital piracy has been based. Two related arguments might run against this heavy-handed approach. First, market conditions might incentivise piracy. Additionally, there are raising doubts over the argument that piracy is a threat to creativity, especially in the digital environment. In a study edited by Joe Karaganis, Media Piracy in Emerging Economies, the drafters have noted: "Media piracy has 
been called "a global scourge", "an international plague", and "nirvana for criminals", but it is probably better described as a global pricing problem. High prices for media goods, low incomes, and cheap digital technologies are the main ingredients of global media piracy" (Karaganis, 2011, p. i). Commenting on the same point, another study continues:

\title{
[c]ounterfeiters are only so widespread because of the exorbitant price of original editions, a price which in itself is the result of privileges. A book whose circulation will be free and which will not be sold even a third above its [true] price, will almost never be counterfeited. Liberty in this sphere, as in every other, has the effect of bringing everything back to its natural price, and everyone to his natural right.
}

Actually, this is the Marquis de Condorcet, making this point roughly two hundred thirty years ago in his Fragments on the Freedom of the Press (de Condorcet, 1776). Indeed, reading Karaganis' report, it seems that we did not get the point. Today, in most of the world, licit media goods are still luxury goods as much as in Condorcet's pre-revolutionary France, and high pricing becomes the first driver for piracy. Ironically, as the Karaganis report argued, the failure of providing affordable access and the strategy of being as aggressive as possible towards any sign of international intellectual property piracy actually encourages, rather than reduces, piracy in the aggregate (Karaganis, 2011, p. 29).

The argument that digital piracy is an extraordinary threat to creativity is the other problematic factor of the equation that would like to demonstrate that expansion of copyright and harsher enforcement is needed. There is no clear evidence on the effects of copyright infringement in the digital environment, the scale of it, the nature of it, or the effectiveness of more aggressive enforcement strategies. In a recent and authoritative report commissioned by the UK government, Digital Opportunity. A Review of Intellectual Property and Growth, Professor Ian Hargreaves noted:

\begin{abstract}
The question is: in a digital world, where copying and distribution are more or less free, what does an effective regime look like? No one doubts that a great deal of copyright piracy is taking place, but reliable data about scale and trends is surprisingly scarce. Estimates of the scale of illegal digital downloads in the UK ranges between 13 per cent and 65 per cent in two studies published last year. A detailed survey of UK and international data finds that very little of it is supported by transparent research criteria. Meanwhile sales and profitability levels in most creative business sectors appear to be holding up reasonably well. We conclude that many creative businesses are experiencing turbulence from digital copyright infringement, but that at the level of the whole economy, measurable impacts are not as stark as is sometimes suggested (Hargreaves, 2011, p. 10).
\end{abstract}

Again, the Karaganis study reinforced the same point by noting that "[a]t the risk of over generalizing, we see a serious and increasingly sophisticated industry research enterprise embedded in a lobbying effort with a historically very loose relationship to evidence" (Karaganis, 2011, p. 4). Hargreaves and Karaganis hint at a key question of the debate over digital piracy. Copyright policies and anti-piracy strategies should be based on hard and transparent evidence. Unfortunately, this evidence was never provided. Rather, the industry appears to push a "faith- 
based intellectual property" approach that is "ultimately unpersuasive and a step backward in a rational society" (Lemley, 2015b, 1328). For some time now, the entertainment industry has been seeking expansion and extension of copyrights and copyright enforcement beyond any factual evidence of the welfare attached to it, which runs counter the traditional-at least in the United States-utilitarian justification of intellectual property rights.

The piracy debate has been led predominantly by the industry supplying the governments with their own biased figures. Governmental institutions have been generally content with those figures and have overlooked any argument to the contrary, making policy based on lobbying, rather than evidence (Horten, 2011).11 One exception has been the Swiss government. In December 2011, the Swiss government decided that there was no need for change in the legal framework to tackle illegal downloading (Swiss Federal Council, 2011, 30 November). The Swiss decision was based on a study conducted by the government into the impact downloading has on society (Swiss Federal Council, 2011, August). The study found that digital piracy has no proven negative impact on the production of national culture. In fact, illegal downloading was found to be a phenomenon that is complementary and not alternative to legal purchase of authorised content. The overall suggestion of the Swiss government to the industry is that they should adapt to the change in consumer behaviour, because "every time a new media technology has been made available $[\ldots]$ it has always been 'abused'... [t]his is the price we pay for progress ... [w]inners will be those who are able to use the new technology to their advantages and losers those who missed this development and continue to follow old business models" (Ibid., p. 12).

Many independent studies cast doubts on the conclusion of the industry regarding the effects of piracy, by pointing at the misleading nature of their figures (Grassmuck, 2010, 8 October; Rogers, Szamosszegi \& Jaszi, 2007).12 National and international institutional reports admitted that piracy estimates are bogus and legalisation is a better option than repression (U.S. Government Accountability Office Report, 2010; Huygen, Helberger, Poort, Rutten \& Van Eijk, 2009; Italian Communication Authority, 2010; Social Science Research Council, 201013). A recent study of the Institute for Prospective Technological Studies, a Joint Research Centre of the European Commission, has plainly found "no evidence of digital music sales displacement", after analysing the effects of illegal downloading and legal streaming on the legal purchases of digital music, using clickstream data on a panel of more than 16,00o European consumers (Aguiar \& Martens 2013, pp. 2, 15-16). In fact, the study continues, "Internet users do not view illegal downloading as a substitute to legal digital music" and all the "results suggest that the vast majority of the music that is consumed illegally by the individuals in our sample would not have been legally purchased if illegal downloading websites were not available to them" (Ibid., pp. 1, 16). In response to studies discussing negative impact of file sharing on the music industry (Liebowitz, 2007; Liebowitz, 2006; Rob \& Waldfogel, 2007; Rob \& Waldfogel, 2006; Zentner, 2006), an highly regarded study from Oberholzer-Gee and Strumpf has generally noted that the cannibalisation of sales that is due to file sharing is more modest than many observers assume and no more than $20 \%$ of the recent decline in sales is due to sharing (Oberholzer-Gee \& Strumpf, 2010, p. 19). In fact, a recent study from Robert Hammond found that pre-release Bit Torrent piracy causes an increase in album sales (Hammond, 2012). In any event, even if filesharing has reduced revenues, other technological changes have reduced the costs of bringing creative works to market (Waldfogel, 2011, pp. 4, 23). Finally, the decline in the sales of physical copies of recorded music cannot be attributed solely to file-sharing, but should be explained by a combination of factors such as changing patterns in music consumption, decreasing disposable household income for leisure products and increasing sales of digital content through online platforms (Cammaerts \& Meng, 2011; Tschmuck, 2010, 29 March). 


\section{IS THE SKY FALLING OR OPENING UP?}

The sky is perhaps opening up, rather than falling, as the entertainment industry claims (Carrier, 2015, 13 May; Masnick \& Ho, 2012; Waldfogel, 2011, 14 November; Cooper, 2008, pp. 14-24). A recent report from Michael Masnick and Michael Ho has noted that the claims about the declining state of the entertainment industry "simply don't match up to reality" (Masnick \& Ho, 2012, p. 1). Actually, the market for music, film and video, video games, and books has been blooming throughout the last decade. The value of the worldwide entertainment industry has grown nearly fifty percent. Employment in the US entertainment sector has increased by nearly twenty percent. The amount of new content being produced worldwide has grown at a tremendous rate in any area of the entertainment industry. Finally, more importantly, the total US household spending that went to entertainment grew by fifteen percent (Ibid., pp. 1-3).

Rather than a threat, easier copying and illegal distribution in peer-to-peer networks may turn out to be an opportunity for creativity and creators. Focusing on the innovative potential of piracy practices, many researchers have attempted to unveil the great lie of the negative impact of digitalisation on the market for creativity. Firstly, on the side of the incentive of authors to produce new works, file sharing appears not to have affected both quantity and quality of music production. As a series of studies from Joel Waldfogel has demonstrated, there is no evidence that the volume of high-quality music, or consumers, have suffered (Waldfogel, 2011) or that changes since Napster have affected the quantity of new recorded music or artists coming to market (Waldfogel, 2011b).14 In fact, a substantial increase in quality is suggested since 1999 (Waldfogel, 2011, pp. 4, 24). According to Oberholzer-Gee and Strumpf, since the advent of file sharing, production of music, books and movies has increased sharply (Oberholzer-Gee \& Strumpf, 2010, pp. 19-20).

As far as incomes are concerned, studies have found that artists seem to be better off in the file sharing era than ever before. Actually, file sharing increases the demand for complements to protected works, raising, for instance, the demand for concerts and concert prices. A recent Harvard report showed that the classical revenues sources shift from recordings to concerts and concluded that broader illegitimate distribution of digital goods may have off-setting demand implications for legitimate sales of complementary non-digital products, such as live performance revenues for small artists (Mortimer, Nosko \& Sorensen, 2010). Again, Oberholzer-Gee and Strumpf have concluded that the sale of more expensive complements has added to artists' incomes (Oberholzer-Gee \& Strumpf, 2010, p. 19). In a similar fashion, a Norwegian study, limited to the national market of that country, has shown that artists make more money in the file-sharing era than ever before (Bjerkøe \& Sørbo, 2010).15 In particular, the Norwegian study has found a thirty percent growth in the number of artists and a sixty percent growth in their specific average income. In fact, positive effects on authors of piracy practices causing large exposure to the public are nothing new under the sun. Jerome K. Jerome, the author of Three Men in a Boat (To Say Nothing of the Dog), once said:

In Chicago, I was assured by an enterprising pirate now retired, that the sales throughout the United States had exceeded a million; and although, in consequence of its having been published before the Copyright Convention, this has brought me no material advantage, the fame and popularity it has won for me among the American public is an asset not to be despised (Jerome, 1909). 
Additionally, diversity of musical production has been enhanced since the advent of peer-topeer file sharing. The Harvard report cited earlier found an increase in diversity with a greater number of artists on tour, almost 95\% more in 10 years (Mortimer, Nosko \& Sorensen, 2010). This is firstly due to the occurrence that non-market sharing leads to more diversity in the attention given to various works, as recent empirical research demonstrates (Aigrain, 2012, pp. 31-43, 181-192). Independent artists are thriving, with their numbers growing steadily and substantially, and independent labels accounting for a growing share of successful music, measured by both critical acclaim and sales (Masnick \& Ho, 2012, p. 5-6; Waldfogel, 2011, pp. 23).16

However, it is on the side of the positive effects on consumption of cultural goods that the digital threat discourse is debunked more consistently. In general, expenditure on entertainment-based goods has risen considerably since the advent of the internet. Specifically, studies have largely found that file-sharers tend to spend more on cultural goods on the internet than any other category. These studies have sampled a very large and diverse user base from a large number of countries, including Canada, the United Kingdom, the Netherlands, France, Germany and Norway. The conclusion that file sharers consume more cultural goods has been consistent among very diverse research studies. For example, a Dutch study has noted that "when it comes to attending concerts, and expenses on DVDs and games, file sharers are the industry's largest customers [ ... [a]ficionados of music, games or films will typically buy more, get into related products more but also download more" (van Eijk, Poort \& Rutten, 2010).

A Canadian study has carried out a measurement of the extent to which free music downloads, including the use of $\mathrm{P}_{2} \mathrm{P}$ file sharing networks, act as substitutes or complements to music purchase in markets for CDs and electronic delivered music (such as in MP3 format) in Canada and noted that "those who participate in free music downloading and P2P file-sharing do not purchase more or less music compared with those who do not engaged in such activities, but that, indeed, very active file-sharers purchase more music relative to file-sharers who download fewer songs" (Andersen \& Frenz, 2008). Again, another study has concluded that Vuze P2P networks users are the best consumers for Hollywood (Magid, F. Associates, Inc., 2009). IPSOS studies in Germany and the UK have equally found out that German and British file-sharers are better "consumers" of culture than the internet users who do not download illegally (Ipsos MediaCT, 2009). Even a study released by the French HADOPI organisation came down to the same finding (HADOPI, 2011; Karaganis, 2011, 26 July).

Evidence of misperceived internet piracy threats might be found also in the movie anime sector. Japanese anime and manga comic art enjoys a very large international market. Illegal online distribution of anime has always been claimed by the entertainment industry as leading to billions of dollars in losses worldwide. In a surge of enforcement, the American anime distributor Funimation announced lawsuits against thousands of alleged BitTorrent downloaders (“Anime Distributor Launches Piracy Assault”, 2011). However, the Japanese Research Institute of Economy, Trade and Industry (RIETI), an economics think-tank of the Japanese government, published a study concluding that online piracy of anime shows actually increases sales of DVDs (Tatsuo, 2011). The study examined the effects of the movie sharing site YouTube and file sharing programme Winny on DVD sales and rentals of Japanese animation programmes. The study concluded that 
sales. Youtube's effect of boosting DVD sales can be seen after the TV's broadcasting of the series has concluded, which suggests that not just a few people learned about the program via a Youtube viewing. In other words YouTube can be interpreted as a promotion tool for DVD sales.

Similarly, a suppressed study by the German Society for Consumer Research (GfK) found that users of pirate sites actually buy more movies and treat these services as a preview ("Suppressed Report Found”, 2011). Unfortunately, the unnamed sponsors commissioning the report decided not to disclose the unexpected findings. In contrast, former Google Chief Information Officer and EMI Chief Operating Officer Douglas Merrill has been less concerned to disclose his profiling research at EMI records. Merrill revealed that his research found that LimeWire pirates were iTunes' biggest customers ("Former Google CIO", 2011). The conclusion that piracy may equal to promotion of copyrighted content is in line with the findings of many of the studies mentioned earlier. Across many different sectors, hard data seem to suggest that the entertainment industry misperceived the internet as threat.

Wrapping up on these findings, even if sellers' revenues have decreased - and this is regardless of authors' revenues and the overall market for cultural goods - what matters for consumers, however, is the surplus they derive from new cultural outputs. This, by the way, matters also from a constitutional standpoint, at least in the United States. In the end, today there is little factual justification for policy decisions based on a digital threat discourse. As the legal monopoly created by copyright is mainly justified by its encouragement in the creation of new works, technology has not affected the balance of that relationship, being "clear that creative output in recorded music [for example] is as high, or higher, than it was prior to Napster" (Waldfogel, 2011, p. 24).

\section{CONCLUSION: PIRACY AS INNOVATION POLICY?}

On a broader perspective, the question of piracy is historically far more complex than what the conclusions of the entertainment industry would like to demonstrate. As Adrian Johns argued, in fact, piracy has always stood at the centre of our attempts to reconcile creativity and commerce. Piracy has been an engine of social, technological, and intellectual innovations as often as it has been their adversary (Johns, 2010). This phenomenon has been strengthened by the users' involvement with creation and distribution of cultural outputs in the digital environment. The users' capacity of being ahead of the industry has been forcing the industry to innovate at a faster speed. In this respect, users' piracy, illegal downloading and streaming become a driver for innovation.

The global simulcast of the last episode of Lost is a good case on point. Traditionally, we have gotten used to distribution of international TV shows months or even years after the original broadcast. The fear of illegal downloading and streaming of the last episode of Lost forced Abcthe producer and distributor of Lost - to accelerate drastically distribution worldwide. Fox in Italy, Spain and Portugal, Sky 1 in United Kingdom, Digiturk in Turkey and HOT in Israel broadcast this "media event" concomitantly with the broadcast in the United States. Fifty-nine other countries released the episode within 24/48 hours from the original broadcast. From a broader perspective, it is undeniable that widespread distaste or disrespect for copyright (Sibely, 2015; Tehranian 2011, xvi-xxi; Litman, 2010, pp. 3-5, 31-32; Lunceford \& Lunceford, 2008; Lange, 471) lead to the emergence of alternative business models that contributed to lower 
prices and enhance users' experience-such us iTunes, Spotify, and Pandora-or institute an unrestrained discourse between authors and public-such as Bandcamp, TopSpin, or Kickstarter (Frosio forthcoming, 57-64),

In most instances, piracy is the result of the industry's incapacity to cope with the demands of the public. In a globalised and interconnected cultural environment, splitting the market in different distribution zones has an increasing negative impact on users. Piracy follows as a reaction to a market practice that the users seem to dislike. As with the case of Lost or the case of high-pricing of media products, piracy increasingly develops as a reaction to unfair or unsatisfactory market practices, or practices that are at least perceived as such by the user base. In a Canadian study, this process is statistically quantified and described by noting that "in essence, the behavioural incentives underpinning free music downloading are the effects of 'unwilling to pay' (market substitution), 'hear before buying' (market creation), 'not wanting to buy whole albums' (market segmentation), 'not available in the $\mathrm{CD}$ format or on electronic paysites (market creation)"' (Andersen \& Frenz, 2008, p.1; Ponte, 2008).17

As Matt Mason noted, “[w]hen pirates start to appear in a market it's usually an indication that it isn't working properly ... [piracy] is how inefficient systems are replaced” (Mason, 2008, p. 66-67).18 Again, Mike Masnick followed up by stating an obvious concept that often the industry seems to miss: "still, the best way to respond to unauthorized file sharing is to make authorized services more convenient" (Masnick, 2013). This applies with reinvigorated actuality, for example, to illegal online streaming of copyrighted content at live sports events. At least in Europe, linking parties-such as Rojadirecta, Allowstreaming, or ThePirateBay-are generally found secondarily liable to the primary infringer (Frosio, 2015; C More Entertainment v Sandberg, 2015; Frosio, 2013, 6 September).

As we have seen earlier, intermediaries have been co-opted in the battle against illegal streaming online. Access service providers are routinely requested to implement blocking orders against sites linking to illegal online streaming (Frosio, 2013, 22 September; Frosio, 2013, 22 September). In multiple instances, search engines have been ordered to set up proactive monitoring tools to expunge the internet from entries linking to infringing content. Also in the case of illegal online streaming, piracy emerges because content is too pricey or wholly unavailable due to distribution restrictions imposed by content licensing. Therefore, piracy becomes the symptom of a market inefficiency that should be cured by meeting users' demands rather than heavy-handed enforcement approaches and over-expanding intermediary liability. Evidence-based data run counter reactionary policy approaches focusing on market disruption, rather than the overall surplus that the public derives-and might increasingly derive-from digital technology. The enforcement rush-increasingly through miscellaneous forms of liability for online intermediaries-does not find factual justification according to the literature. In contrast, it might lead further away from the primary goal of copyright law that is-according to dominant welfare theory and emerging cultural theory ${ }_{19}$-the encouragement of the creation of new works and their broadest distribution to the general public. Today-according to empirical evidence-creative output and access is on the rise in the digital environment. Apparently, we do not need more enforcement, either against primary or secondary infringement. 


\section{REFERENCES}

Acceso a Internet es un derecho fundamental. (2010, 8 September). Retrieved from http://www.nacion.com/2010-09-08/ElPais/NotasSecundarias/ElPais2514038.aspx.

AGCOM (2013, 12 December). AGCOM Regulations regarding Online Copyright Enforcement. 680/13/CONS. Retrieved from

http://www.agcom.it/documents/10179/o/Documento/bo41of3a-0586-449a-aa99-09ac8824c 945 .

Aguiar, L. \& Martens, B. (2013). Digital Music Consumption on the Internet: Evidence from Clickstream Data. Institute for Prospective Technological Studies Digital Economy Working Paper 2013/04. Retrieved from http://ipts.jrc.ec.europa.eu/publications/pub.cfm?id=6084.

Aigrain, P. (2012). Sharing: Culture and the Economy in the Internet Age 31-43, 181-192 (Amsterdam University Press 2012). Retrieved from http://www.sharing-thebook.com.

Andersen, B. \& Frenz, M. (2008), The Impact of Music Downloads and P2P File-sharing on the Purchase of Music in Canada. DIME Working papers on Intellectual Property Rights No. 82. Retrieved from http://www.dime-eu.org/files/active/o/WP82-IPR.pdf.

Anime Distributor Launches Piracy Assault, Sues 1337 BitTorrent Users. (2011, 26 January). Retrieved from

http://torrentfreak.com/anime-distributor-launches-piracy-assault-sues-1337-bittorrent-users110126.

Anti-Piracy Group Hits Indie Creators for Using the Word 'Pixels'. (2015, 8 August). Retrieved from https://torrentfreak.com/anti-piracy-group-hits-indie-creators-for-using-the-wordpixels-150808.

APC et al v Google, Microsoft, Yahoo!, Bouygues et Al (TGI Paris 2013). Retrieved from http://static.pcinpact.com/medias/jugement-allostreaming-20131129.PDF.

Belen v Google, R.522.XLIX. (Argentinian Supreme Court 2014). Retrieved from https://cyberlaw.stanford.edu/page/wilmap-argentina.

Benabou, V. (2010). The Chase: The French Insight into the 'Three Strikes' System. In I. Stamatoudi, Copyright Enforcement and the Internet. Alphen aan den Rijn, Netherlands: Wolters Kluwer.

Bjerkøe, R. \& Sørbo, A. (2010). The Norwegian Music Industry in the Age of Digitalization Unpublished Master Thesis). BI Norwegian School of Management, Norway. Retrieved from http://www.scri bd.com/doc/37406039/Thesis-Bjerkoe-Sorbo.

Boyle, J. (2009). The Public Domain: Enclosing the Commons of the Mind. New Heaven: Yale University Press.

Brand, S. (1986). The Media Lab: Inventing the Future at MIT. London: Penguin Books.

Cammaerts, B. \& Meng, B. (2011). Creative Destruction and Copyright Protection: Regulatory Responses to File-sharing. London School of Economics Media Policy Project. Retrieved from http://www.scribd.com/doc/51217629/LSE-MPPbrief1-creative-destruction-and-copyright-prot ection. 
Carrier, M. (2015, 13 May). No, RIAA, It's Not The End Of The World For Musicians. Techdirt. Retrieved from https://www.techdirt.com/articles/20150512/13343330980/no-riaa-not-endworld-musicians.shtml.

Carrier, M. (2014). No, RIAA, It's Not the End of the World for Musicians. UMKC L. Rev., 82. Retrieved from http://papers.ssrn.com/sol3/papers.cfm?abstract_id=2602469.

Cartier et al. v BSkyB et al., [2014 EWHC 3354 (Ch) (High Court of Justice 2014). Retrieved from

http://www.bailii.org/cgi-bin/markup.cgi?doc=/ew/cases/EWHC/Ch/2003/3354.html\&query $=$ Cartier\&method=boolean .

Center For Democracy \& Technology (CDT) (2010). Campaign Takedown Troubles: How Meritless Copyright Claims Threaten Online Political Speech. Retrieved from http://www.cdt.org/files/pdfs/ copyright_takedowns.pdf.

C More Entertainment v Sandberg, C $\square$ 279/13 (European Court of Justice 2015). Retrieved from https://cyberlaw.stanford.edu/page/wilmap-european-union.

Conley, M. \& C. Patterson (2000). Human Rights And The Internet. London, UK: Macmillan.

Cooper, M. (2008). Round \#1 of the Digital Intellectual Property Wars: Economic Fundamentals, Not Piracy, Explain How Consumers and Artist Won in the Music Sector. Stanford Center for Internet and Society Research Paper. Retrieved from http://cyberlaw.stanford.edu/system/files/digitalmusicarticlecirculation.pdf.

Crossley, D. (2014, 5 February). Case Law, Hamburg District Court: Max Moseley v. Google Inc, Google Go Down (Again, this Time:) in Hamburg. Inforrm's Blog. Retrieved from https://inforrm.wordpress.com/2014/02/05/case-law-hamburg-district-courtmax-mosley-v-google-inc-google-go-down-again-this-time-in-hamburg-dominic-crossley

Dara, R. (2011). Intermediary Liability in India: Chilling Effects on Free Expression on the Internet. Center for Internet and Society Bangalore. Retrieved from

http://cis-india.org/internet-governance/intermediary-liability-in-india.pdf.

de Condorcet, N. (1776). Fragments on the Freedom of the Press. Paris, France: AmbroiseFirmin Didot. In B. Lionel \& M. Kretschmer, F. Baetens trans., Primary Sources on Copyright (1450-1900). Retrieved from

http://www.copyrighthistory.org/cgi-bin/kleioc/o010/exec/ausgabe/\%22f_1776a\%22.

Delfi AS v Estonia, No. 64569/o9 (ECHR 2015).

Delta TV v YouTube, IP Specialized Section (Tribunal of Turin 2014). Retrieved from https://cyberlaw.stanford.edu/page/wilmap-italy.

Ermert, M. (2009). Council of Europe: Access to Internet is a Fundamental Right IPWatch. Retrieved from http://www.ip-watch.org.

European Commission (2015). Communication. A Digital Single Market Strategy for Europe. $\operatorname{COM}(2015) 192$ final. Retrieved from

http://ec.europa.eu/priorities/digital-single-market/docs/dsm-communication_en.pdf.

Finland Makes Broadband a 'Legal Right'. (2010, 1 July). Retrieved from 
http://www.bbc.co.uk/news/10461048.

Fisher, W. (2001). Theories of Intellectual Property. In Stephen Munzer, New Essays in the Legal and Political Theory of Property. Cambridge, UK: Cambridge University Press. Retrieved from http://cyber.law.harvard.edu/people/tfisher/IP/Fisher_IP_Theories.pdf.

Former Google CIO: LimeWire Pirates were iTunes' Best Customers. (2011, July 26). Retrieved from

http://torrentfreak.com/former-google-cio-limewire-pirates-were-itunes-best-customers-11072 6.

Frabboni, M. (2010), File Sharing and the Role of Intermediaries in the Marketplace: National, European Union and International Developments. In I.. Stamatoudi, Copyright Enforcement And the Internet. Alphen aan den Rijn, Netherlands: Wolters Kluwer.

Frosio, G. (2015, 31 March). (C) More Entertainment for Broadcasters: The European Court of Justice on Linking to Live Streams of Sport Events. CIS Blog. Retrieved from https://cyberlaw.stanford.edu/blog/2015/o3/c-more-entertainmentbroadcasters-european-court-justice-linking-live-streams-sport.

Frosio, G. (2014, 7 November). Cartier vs BSkyB: UK Judge Orders ISPs to Block Websites Infringing Trademarks for the First Time in Europe. CIS Blog. Retrieved from https://cyberlaw.stanford.edu/blog/ 2014/11/cartier-vs-bskyb-uk-judge-orders-isps-blockwebsites-infringing-trademarks-first-time.

Frosio, G. \& P. Vargas (2014, 5 November). Argentine Supreme Court Decides Landmark Intermediary Liability Case. CIS Blog. Retrieved from

https://cyberlaw.stanford.edu/blog/2014/11/argentine-supreme-court-decides-landmark-inter mediary-liability-case.

Frosio, G. (2014, 31 January). Brazilian Supreme Court Found Google Liable for Commercial Videos Parodying Dafra's Commercials. Stanford CIS Blog. Retrieved from http://cyberlaw.stanford.edu/blog/ 2014/o1/brazilian-supreme-court-found-google-liablevideos-parodying-dafra-commercials.

Frosio, G. (2013, 17 December). Italian Communication Authority Approves Administrative Enforcement of Online Copyright Infringement. CIS Blog. Retrieved from https://cyberlaw.stanford.edu/blog/2013/12/ italian-communication-authority-approvesadministrative-enforcement-online-copyright.

Frosio, G. (2013, 22 September). UK High Court Orders ISPs to Block IP Address, Erroneously Takes Down Hundreds of Sites. CIS Blog. Retrieved from

https://cyberlaw.stanford.edu/blog/2013/o9/uk-highcourt-orders-isps-block-ip-address-erroneously-takes-down-hundreds-sites.

Frosio, G. (2013, 6 September). Alalalai! . . Rojadirecta is Up for Battle Again in Italy. CIS Blog. Retrieved from https://cyberlaw.stanford.edu/blog/2013/o9/alalalai-rojadirecta-battle-againitaly.

Frosio G. (2011). Urban Guerrilla \& Piracy Surveillance: Accidental Casualties in Fighting Piracy in P2P Networks in Europe. Rutgers Comp. \& Tech L. J., 37, 1. Retrieved from http: $/ /$ ssrn.com/abstract $=1545013$. 
Gentzkow, M. \& J. Shapiro (2010). Ideological Segregation Online and Offline. NBER Working Paper Series No. 15916/10. Retrieved from http://www.nber.org/papers/w15916.

Ginsburg, J. (2010). User-Generated Content Sites and Section 512 of the US Copyright Act. In I.. Stamatoudi, Copyright Enforcement And the Internet. Alphen aan den Rijn, Netherlands: Wolters Kluwer.

Google Brazil v Dafra, Special Appeal No. 1306157/SP (Superior Court of Justice, Fourth Panel, 24 March 2014). Retrieved at https://cyberlaw.stanford.edu/page/wilmap-brazil.

Grassmuck, V. (2010, October 8). What do we know about the Impact of P2P File-Sharing on the Music Industry? A Literature Review. Free Culture Conference, Freie Universität, Berlin. Retrieved from http://wikis.fu-berlin.de.

HADOPI (Haute Autorité pour la diffusion des oeuvres et la protection des droits sur internet). (2011, 23 January). Hadopi, biens culturales et usages d'internet: practiques et perceptions des internautes français. Retrieved from http://www.hadopi.fr/download/hadopiTo.pdf.

Halbert D. (2009). Mass Culture and the Culture of the Masses: A Manifesto for User-Generated Rights. Vand. J. Ent. \& Tech. L., 11, 921.

Hammond, R. .(2012) Profit Leak? Pre-Release File Sharing and the Music Industry. North Carolina State University Working Paper Series. Retrieved from

http://www4.ncsu.edu/ rghammon/ Hammond_File_Sharing_Leak.pdf.

Hargreaves, I. (2011). Digital Opportunity. A Review of Intellectual Property and Growth. UK Intellectual Property Office. Retrieved from http://www.ipo. gov.uk/ipreview-finalreport.pdf.

Heins, M. \& T. Beckles (2004). Will Fair Use Survive? Free Expression in the Age of Copyright Control. A Public Policy Report. Brennan Center For Justice. Retrieved from http://www.fepproject.org/policyreports/WillFairUseSurvive.pdf.

Horten, M. (2011, 25 August). Hargreaves Response: The Sharp Under-Belly of Enforcement. IPtegrity.com. Retrieved from

http://www.iptegrity.com/index.php/digital-britain/685-hargreaves-response-the-sharp-under -belly-of-enforcement.

Horten, M. (2011). The Copyright Enforcement Enigma: Internet Politics and the 'Telecoms Package'. London, UK: Palgrave Macmillan 2011.

Hughes, J. (1988). The Philosophy of Intellectual Property. 77 Georgetown L.J., 77, 287. Retrieved from http://www.justinhughes.net/docs/a-ipo1.pdf.

Huygen, A., Helberger, N., Poort J., Rutten, P. \& Van Eijk, N. (2009). Ups and Downs: Economic and Cultural Effects of File sharing on Music, Film and Games. Ministries of Education, Culture and Science, Economic Affairs and Justice of the Netherlands. Retrieved from http://papers.ssrn.com/sol3/papers.cfm?abstract_id=1350451.

International Federation of the Phonographic Industries (IFPI) (2012). Digital Music Report 2012. Expanding Choice. Going Global. Retrieved from

http://www.ifpi.org/content/library/DMR2012.pdf.

IFIP (2010), Digital Music Report 2010: Music How, When, Where You Want It. Retrieved from 
http://www.ifpi.org/content/library/DMR2010.pdf.

Internet Access is a 'Fundamental Right'. (2010, March 8). Retrieved from

http://news.bbc.co.uk/2/hi/technology/854819o.stm.

Ipsos MediaCT. (2009, 19 October) Digital Music Survey: Illegal Downloaders Spend More On

Music. Retrieved from http://www.demos.co.uk/files/DemosMusicsurvey.ppt

Italian Communication Autority (2010) [Autorità per le Garanzie nelle Comunicazioni,

AGCOM]. Il Diritto d'Autore sulle Reti di Comunicazione Elettronica, Indagine Conoscitiva.

Retrieved from

http://www.agcom.it/Default.aspx?message=visualizzadocument\&DocID=379o.

Jerome, J. (1909). Author's Advertisement.

JETL 10th Anniversary Symposium (2007, 2 November). User-generated Confusion: The Legal and Business Implications of Web 2.o. Vanderbilt University. Retrieved from

http://law.vanderbilt.edu/publications/journal-entertainment-technology-law/index.aspx.

Johns, A. (2010). Piracy: The Intellectual Property Wars from Gutenberg to Gates. Chicago,

MI: University of Chicago Press.

Karaganis, J. (2011). Introduction. In J. Karaganis, Media Piracy in Emerging Economies.

Social Science Research Center. Retrieved from

http://www.scribd.com/doc/50196972/MPEE-1-0-1.

Karaganis, J. (2011). Rethinking Piracy. In J. Karaganis, Media Piracy in Emerging Economies. Social Science Research Center. Retrieved from

http://www.scribd.com/doc/50196972/MPEE-1-0-1.

Karaganis, J. (2011, 26 July). HADOPI Says: Let's Try Cutting off Nose to Spite Face. SSRC

Media Piracy in Emerging Economies. Retrieved from

http://piracy.ssrc.org/hadopi-says-lets-try-cutting-off-nose-to-spite-face.

Keller, D. (2015, 12 October). Empirical Evidence of "Over-Removal” by Internet Companies Under Intermediary Liability Laws. CIS Blog. Retrieved from

https://cyberlaw.stanford.edu/blog/2015/10/empirical-

evidence-over-removal-internet-companies-under-intermediary-liability-laws.

David Lange, D. (2003). Reimagining The Public Domain. Law \& Contemp. Probs., 66, 475.

Retrieved from

http://scholarship.law.duke.edu/cgi/viewcontent.cgi?article=1284\&context=lcp.

Lasica, J. D. (2005). Darknet: Hollywood's War Against the Digital Generation. Hoboken, NJ: Wiley \& Sons.

Lemley M. (2015). IP in a World without Scarcity. N.Y.U. L. Rev., 90, 460. Retrieved from http://www.nyulawreview.org/sites/default/files/pdf/NYULawReview-90-2-Lemley.pdf.

Lemley, M. (2015b). Faith-based Intellectual Property. UCLA L. Rev., 62, 1328. Retrieved from http://ssrn.com/abstract=2587297.

Lenz v Universal, 5:07-cv-03783-JF (9th Cir. 2015). Retrieved from 
http://cdn.ca9.uscourts.gov/datastore/opinions/2015/09/14/13-16106.pdf.

Lesser, J. (2013). Copyright Alert System Set to Begin, Center for Copyright Information. Retrieved from

http://www.copyrightinformation.org/uncategorized/copyright-alert-system-set-to-begin .

Lessig, L. (2010, March 16). Italy and the Internet. The Huffington Post. Retrieved from http://www.huffingtonpost.com/lawrence-lessig/italy-and-the-internet_b_500430.html.

Lichtman, D. (2008). Copyright as Information Policy: Google Book Search from a Law and Economics Perspective. In J. Lerner \& S. Stern, Innovation Policy And The Economy, 9. Cambridge, MA: NBER.

Liebowitz, S. (2007). How Reliable is the Oberholzer-Gee and Strumpf Paper on File-Sharing? University of Texas at Dallas Working Paper. Retrieved from

http://copyrightalliance.net/files/ssrn-id1014399.pdf.

Liebowitz. S. (2006). File Sharing: Creative Destruction or Just Plain Destruction? J. L. \& Econ., $49,1$.

Litman, J. (2010). Real Copyright Reform. Iowa L. Rev., 96, 1.

Lunceford, B. \& Lunceford, S. (2008). The Irrelevance Of Copyright In The Public Mind, Nw. J. Tech. \& Intell. Prop., 7, 33 (2008).

Magid, F. Associates, Inc. (2009, 2 June). Introducing Hollywood's Best Customers - Vuze User vs. General Internet: Comparative Data. Retrieved from http://www.magid.com/sites/default/files/pdf/vuze.pdf.

Mara, K. (2010, 28 September). Internet Access And Human Rights Highlighted Alongside UN Human Rights Council. IPWatch. Retrieved from http://www.ip-watch.org.

Mara, K., (2010, 10 May). ITU-UNESCO Broadband Commission Aims at Global Internet Access. IPWatch. Retrieved from http://www.ip-watch.org.

Masnick, M. (2013, 22 March). A Tale of Two Studies: Can File Sharing Both Harm and Help Sales? Techdirt. Retrieved from

https://www.techdirt.com/articles/20130321/10201522406/tale-two-studies-can-file-sharing-b oth-harm-help-sales.shtml.

Masnick, M. \& Ho, M. (2012). The Sky is Rising: A Detailed Look at the State of the Entertainment Industry. Floor 64. Retrieved from http://www.techdirt.com/skyisrising

Mason, M. (2008). The Pirate's Dilemma: How Hackers, Punk Capitalists, Graffiti Millionaires and Other Youth Movements are Remixing Our Culture and Changing Our World. London, UK: Penguin.

McKay, P. (2010). Culture of the Future: Adapting Copyright Law to Accommodate Fan-Made Derivative Works in the Twenty-First Century. Regent U. L. Rev., 24, 117. Retrieved from http://papers.ssrn.com/sol3/papers.cfm?abstract_id=1728150.

Morozov, E. (2012). The Net Delusion: The Dark Side of Internet Freedom. New York, NY: Public Affairs. 
Morozov, E. (2010). Think Again: The Internet. Foreign Policy. Retrieved from http://www.foreignpolicy.com/articles/2010/04/26/think_again_the_internet.

National Research Board (2000). The Digital Dilemma: Intellectual Property in The Information Age. Washington: National Academy Press.

Oberholzer-Gee, F. \& Strumpf, K. (2010). File-Sharing and Copyright. Innovation Policy and the Economy, 10, 19. Retrieved from http://www.hbs.edu/research/pdf/o9-132.pdf.

Palazzi, P. \& Jurado, M. (2015). Search Engine Liability for Third Party Infringement. J. Intell. Prop. L. \& Pract., 10(4), 244. Retrieved from

http://jiplp.oxfordjournals.org/content/10/4/244.full.pdf+html.

Patten, L. (2007). From Safe Harbor to Choppy Waters: Youtube, the Digital Millennium Copyright Act, and a Much Needed Change of Course. Vand. J. Ent. \& Tech. L., 10, 179.

Peguera, M. (2015, 27 January). Spanish Copyright Reform Enters into Force: Special Focus on Online Intermediaries. CIS Blog. Retrieved from

https://cyberlaw.stanford.edu/blog/2015/o1/spanish-copyright-reform-enters-force-special-foc us-online-intermediaries.

Ponte, L. (2008). Coming Attractions: Opportunities and Challenges in Thwarting Global Movie Piracy. In R. Bird \& S. Jain, The Global Challenge of Intellectual Property Rights. London, UK: Edward Elgar.

Poulter A., \& Smith, W. (2014, October 20). High Court Has Jurisdiction to Order ISPs to Block Websites which Infringe Trade Marks. Bird \& Bird. Retrieved from

http://www.twobirds.com/en/news/articles/2014/uk/high-court-has-jurisdiction-to-order-isps -to-block-websites-which-infringe-trade-marks.

Reichman, J., Dinwoodie G. \& Samuelson P. (2007). A Reverse Notice and Takedown Regime to Enable Public Interest Uses of Technically Protected Copyrighted Works. Berkeley Tech L. J., 22, 982 .

Rob, R. \& Waldfoge, J. (2007). Piracy on the Silver screen. J. Ind. Econ., 55, 379.

Rob, R. \& Waldfoge, J. (2006). Piracy on the High C's: Music Downloading, Sales Displacement, and Social Welfare in a Sample of College Students. J. L. \& Econ., 49, 29.

Rogers, T., Szamosszegi, A. \& Jaszi, P. (2007). Fair Use in the U.S. Economy: Economic Contribution of Industries Relying on Fair Use. Computer \& Communications Industry Association. Retrieved from

http://www.wired.com/images_blogs/threatlevel/2010/o4/fairuseeconomy.pdf.

RTI v Yahoo! Italia, 3821/2011 (Milan Court of Appeal 2015). Retrieved https://cyberlaw.stanford.edu/page/wilmap-italy.

SABAM v Netlog NV, C-360/10, European Court of Justice 2012). Retrieved from https://cyberlaw.stanford.edu/page/wilmap-european-union.

Sang, D. (2014). The State of the Discordant Union: An Empirical Analysis of DMCA Takedown Notices. Va. J. L. \& Tech., 18, 369. Retrieved from http://ssrn.com/abstract=2411915. 
Scarlet Extended SA v SABAM, C-70/10 (European Court of Justice 2011). Retrieved from https://cyberlaw.stanford.edu/page/wilmap-european-union.

Seltzer, W. (2010), Free Speech Unmoored in Copyright's Safe Harbor: Chilling Effects of the DMCA on the First Amendment. Harv. J. L. \& Tech., 24, 171.

Sibley, J. (2015). The Eureka Myth: Creators, Innovators, and Everyday Intellectual Property. Stanford, CA: Stanford University Press.

Sirinelli, P. (2010). The Graduated Response and the Role of Intermediaries: Avoiding the Apocalypse or a Return to the Sources? In L. Bently, U. Suthersanen and P. Torremans, Global Copyright: Three Hundred Years since the Statute of Anne, from 1709 to Cyberspace. London, UK: Edward Elgar.

Social Science Research Council (2010). Piracy and Jobs in Europe: Why the BASCAP/TERA Approach is Wrong. Retrieved from http://blogs.ssrc.org/datadrip/wp-content/uploads/2010/o3/Piracy-and-Jobs-in-Europe-An-S SRC-Note-on-Methods.pdf.

Standeford, D. (2010). Contradictory Court Rulings, Continuing Tension On Internet Liability In EU, IPWatch. Retrieved from

http://www.ip-watch.org/weblog/2010/o2/17/contradictory-court-rulings-continuing-tensionon-internet-liability-in-eu/print.

Strowel, A. (2010). The 'Graduated Response' in France: Is It the Good Reply to Online Copyright Infringements? In I. Stamatoudi, Copyright Enforcement and the Internet. Alphen aan den Rijn, Netherlands: Wolters Kluwer.

Suppressed Report Found Busted Pirate Site Users Were Good Consumers. (2011, July 19). Retrieved from

http://torrentfreak.com/suppressed-report-found-busted-pirate-site-users-were-good-consum ers-110719.

Swartout, C. (2011). Toward a Regulatory Model of Internet Intermediary Liability: File-Sharing and Copyright Enforcement. Northwestern J. Int'l L. \& Bus., 31, 499.

Swiss Federal Council (2011, November 30). Copyright Infringement in the Internet: The Present Legal Framework is Sufficient. Press Release. Retrieved from

http://www.ejpd.admin.ch/content/ejpd/it/home/dokumentation/mi/2011/2011-11-30.html.

Swiss Federal Council (2011, August). Bericht des Bundesrates zur unerlaubten Werknutzung über das Internet in Erfüllung des Postulates 10.3263 Savary [Report of the Federal Council on the Illegal Utilizations of Works in the Internet in Response to the Assumption 10.3263 Savary]. Retrieved from

http://www.ejpd.admin.ch/content/dam/data/pressemitteilung/2011/2011-11-30/ber-br-d.pdf (German and French only).

Tatsuo, T. (2011). Do Illegal Copies of Movies Reduce the Revenue of Legal Products? The case of TV animation in Japan. Research Institute of Economy, Trade Industry discussion paper 11J-010. Retrieved from http://www.rieti.go.jp/en/publications/summary/11010 o21.html.

Tehranian, J. (2011). Infringement Nation: Copyright 2.o and You. Oxford, UK: Oxford 
University Press.

TERA (2010). Building a Digital Economy: The Importance of Saving Jobs in the EU's Creative Industries. Business Action to Stop Counterfeiting and Piracy (BASCAP). Retrieved from http://www.iccwbo.org/bascap/id3536o/index.html.

Transcript of President Barack Obama's November 16, 2009 Town Hall with Chinese students in Shanghai, as released by the White House. (2009, 16 November). Retrieved from http://www.cbsnews.com/stories/2009/11/16/politics/main5670903.shtml?tag=contentMain;c ontentBody.

Tschmuck, P. (2010, 29 March). The Recession in the Music Industry - A Cause Analysis. Music Business Research. Retrieved from

http://musicbusinessresearch.wordpress.com/2010/o3/29/the-recession-in-the-music-industr y-a-cause-analysis.

Universal v Corley, 273 F.3d 429, 6o U.S.P.Q.2d 1953 (2nd Cir. 2001). Retrieved from http://cyber.law.harvard.edu/people/tfisher/IP/2001\%20Corley\%20Abridged.pdf.

UPC Telekabel v Constantin Film, C-314/12 (European Court of Justice 2014). Retrieved from http://curia.europa.eu/juris/liste.jsf?num=C-314/12.

Urban, J. \& Quilter L. (2006). Efficient Process or 'Chilling Effects'? Takedown Notices Under Section 512 of the Digital Millennium Copyright Act. Santa Clara Computer and High Technology L. J., 22, 621. Retrieved from http://ssrn.com/abstract=2210935.

U.S. Government Accountability Office (2010). Report to Congressional Committees, Intellectual Property: Observation on Efforts to Quantify the Economic Effects of Counterfeit and Pirated Goods. GAO-10-423. Retrieved from http://www.gao.gov/new.items/d10423.pdf.

van Eijk, N., Poort, J. \& Paul Rutten, P. (2010). Legal, Economic and Cultural Aspects of File Sharing. Communications \& Strategies, 77, 35, 44 (2010)

Van Eecke, P. \& Dierick, A. (2013, 12 November ). Mosley v Google - Game, Set but not Match yet. Lexology. Retrieved from

http://www.lexology.com/library/detail.aspx?g=910c97bd-2910-4a7b-a8ff-48dc2a7e34fd.

Viacom v YouTube, 10 Civ. 3342 (2nd Cir. 2012). Retrieved from https://cyberlaw.stanford.edu/page/wilmap-united-states.

Waldfogel, J. (2011, 14 November). Is the Sky Falling? The Quality of New Recorded Music Since Napster. VOX. Retrieved from http://www.voxeu.org/index.php?q=node/7274.

Waldfogel, J. (2011). Copyright Protection, Technological Change, and the Quality of New Products: Evidence from Recorded Music Since Napster. NBER Working Paper Series No. 17503/2011. Retrieved from http://www.nber.org/papers.

Waldfogel, J. (2011b). Bye, Bye, Miss American Pie: The Supply of New Recorded Music since Napster. NBER Working Paper Series No. 16882/2011). Retrieved from http://www.nber.org/papers/w16882.

Zeiter, A. (2014, 6 January). New German Government Intends to Expand Hosting Provider Liability. CIS Blog. Retrieved from https://cyberlaw.stanford.edu/blog/2014/o1/new-german- 
government-intends-expand-hosting-provider-liability.

Zentner, A. (2006). Measuring the Effect of File Sharing on Music Purchases. J. L. \& Econ., 49, 63.

Zhong Qin Wen v Baidu, 2014 Gao Min Zhong Zi, No. 2045 (Beijing Higher People’s Court 2014). Retrieved from

http://www.court.gov.cn/zgcpwsw/content/content?DocID=bo11b842-b4df-4819-9015-517018 ecb57c\&KeyWord $=11912$.

\section{FOOTNOTES}

1. A broader discussion of the mechanics and economics of creativity, the advent of novel business models to support creativity in the networked information society, and proposals for reform to align policies for creativity with modern digital creativity, user-generated content, and remix culture can be found in Frosio, G. (forthcoming). Users' Patronage, The Return of the Gift in the "Crowd Society", Mich. St. L. Rev., 2015(5). Retrieved from

http://ssrn.com/abstract=2659659; Frosio, G. (2014). Rediscovering Cumulative Creativity from the Oral Formulaic Tradition to Digital Remix: Can I Get a Witness?. J. Marshall Rev. Intell. Prop. L., 13(2), 341. Retrieved from http://ssrn.com/abstract=2199210.

2. In order to map the international online intermediary liability regime, at Stanford CIS, with the collaboration of an amazing team of contributors across five continents, I have developed and launched the World Intermediary Liability Map (WILMap), a detailed English-language resource comprised of case law, statutes, and proposed laws related to intermediary liability worldwide. Please consider using the WILMap as an additional aid to magnify on the case law and legislation discussed in this short paper. See World Intermediary Liability Map (WILMap), https://cyberlaw.stanford.edu/our-work/projects/world-intermediary-liability-map-wilmap.

3. The Brazilian Superior Tribunal of Justice found Google liable for copyright infringement for YouTube-hosted videos parodying a well-known commercial and imposed proactive monitoring obligation on the online platform (Google Brazil v Dafra, 2014).

4. See Lumen, https://lumendatabase.org formerly Chilling Effects (collecting and analysing legal complaints and requests for removal of online materials, helping internet users to know their rights and understand the law).

5. In particular, Wendy Seltzer noted that "[i]f this takedown procedure took place through the courts, it would trigger First Amendment scrutiny as a prior restraint - silencing speech before an adjudication of unlawfulness. But because DMCA takedowns are privately administered through service providers, they have not received such constitutional scrutiny despite their high risk of error" (Seltzer, 2010, p. 174-175).

6. See Digital Millennium Copyright Act of 1998, Pub. L. No. 105-304, 112 Stat. 2860 (codified at 17 U.S.C. $\S \S 512,1201-1205,1301-1332$ (2006))

7. See Stop Online Piracy Act (SOPA), 112th Congress H.R. 3261, at § 103 (a)(1)(B)(ii)(I) Retrieved from http://judiciary.house.gov/hearings/pdf/112\%20HR\%203261.pdf.

8. See EUSurveys, Regulatory environment for platforms, online intermediaries, data and cloud computing and the collaborative economy. Retrieved from

https://ec.europa.eu/eusurvey/runner/ Platforms. 
9. Recently, the Brazilian Marco Civil da Internet-or Internet Bill of Rights-introduced a civil liability exemption for internet access providers and other internet providers that might undermine the authority of Dafra in future cases. See Marco Civil da Internet, Federal Law no. 12.965, 23 April, 2014, Article 18-21. Retrieved from https://cyberlaw.stanford.edu/page/wilmap-brazil.

10. The Copyright Alert System, What is a Copyright Alert? Retrieved from http://www.copyrightinformation.org/the-copyright-alert-system/what-is-a-copyright-alert (If the user would like to have her "internet experience" back to normal, one option seems to be to complete an online copyright reeducation programme).

11. Monica Horten discussed in a series of blog posts distortion and odd interpretation of the Hargreaves Report by the UK government in order to disregard its conclusions (Horten, 2011, 25 August).

12. See also Studies on File Sharing. La Quadrature du Net. Wiki. Retrieved from http://www.laquadrature.net/wiki/Studies_\%20on_file_sharing_eng

13. Criticising the approach of a previous report prepared by TERA for the Business Action to Stop Counterfeiting and Piracy (TERA, 2010).

14. Waldfogel, 2011b assembled a novel dataset on the number of high quality works released annually, since 1960, derived from retrospective critical assessments of music such best-of-thedecade lists and comparing the quantity of new albums since Napster to 1) its pre-Napster level, 2) pre-Napster trends, and 3) a possible control, the volume of new songs since the iTunes Music Store's revitalization of the single).

15. This may not necessarily be valid everywhere, in particular because Norway has seen an important growth in grants and subsidies which is not witnessed in other countries.

16. According to Masnick and Ho, 2012, the number of independent artists in the US increased of forty-three percent in the last decade, while Waldfogel, mentioned that " $[\mathrm{w}]$ hile the share of the top 100 on independent labels was 50 percent in both the 1980 s and the 1990 , it rose to 60 percent in the period since 1999").

17. Ponte, 2008 detailed the advantages that piracy offers to users - such us quick and easy access, great selection, cheap price, watching your DVDs anywhere in the world, making personal copies, absence of proprietary DRM formats - and the movie industry does not.

18. Mason, M. (2008). The Pirate's Dilemma: How Hackers, Punk Capitalists, Graffiti Millionaires and Other Youth Movements are Remixing Our Culture and Changing Our World. London, UK: Penguin.

19. Fairness, personality, welfare and cultural theories are the four theoretical clusters under which copyright policies have been developed (Fisher, 2001; Hughes, 1988). Historically, personality theories has been very influential in civil law countries, whereas fairness theories defined most common law copyright systems. Welfare theory-as a by-product of utilitarian theories-set the theoretical framework of copyright law in the United States and have become increasingly popular also elsewhere. Cultural theories-a more recent addition to the copyright theoretical landscape-have been widely promoted by leading intellectual property scholarship. 